\title{
A POLITIKA HATÁSA BUDAPEST KÖZLEKEDÉS- FEJLŐDÉSÉT MEGHATÁROZÓ EGYES ELEMEKRE 1990-TŐL NAPJAINKIG
}

\author{
(Effect of Policy of for Mayor Transport Elements \\ of Budapest after 1990)
}

\section{GAAL GYULA - TÖRÖK ÁDÁM}

Kulcsszavak:

közlekedéspolitika városi közlekedés Budapest

Az utóbbi években a fövárosi közlekedés kapcsán csak a hangos botrányok mozgatják meg a médiát és a lakosságot. Nem tudunk örülni az új kerékpárutaknak, a közforgalmú közösségi közlekedés új eszközeinek. Vajon ezek az észre nem vagy alig vett dolgok valóban jelentéktelenek? A tanulmány Budapest közlekedésfejlődését vizsgálja az elmúlt 20 év politikai változásainak tükrében.

\section{Bevezetés}

Cikkünkben a főváros, Budapest városi közlekedéspolitikájával foglalkozunk. Kutatásaink kiindulópontja a rendszerváltás ideje, ekkortól kezdve volt lehetősége a politikai pártoknak (megalakulásokat követően) foglalkozni a témával. Áttekintjük, hogy a meghatározóbb pártok az egyes országgyülési választásokon milyen, Budapest közlekedését érintő intézkedésekre helyezték a hangsúlyt, amelyeket később a kormányzati hatalom birtokában - végre kívántak hajtani. Alapvető szempont volt, hogy azon, a parlamentbe jutási küszöböt elérő pártok választási programjaival foglalkozzunk, amelyek minden ciklusban részt vehettek az országgyülés munkájában. Ezek - kormányra kerülésük időrendjében - a Magyar Demokrata Fórum (MDF), a Magyar Szocialista Párt (MSZP), a Szabad Demokraták Szövetsége (SZDSZ), valamint a Fiatal Demokraták Szövetsége - Magyar Polgári Párt, illetve később Magyar Polgári Szövetség (Fidesz). Mivel célunk Budapest városi közlekedésének vizsgálata, a választási-, illetve a kormányprogramokból a fővárost - akár közvetlen, akár közvetett módon - érintő elemeket vesszük figyelembe.

Célunk olyan kvantitatív adatok kiemelése volt, amelyek segítségével megítélhetővé - és a programpontokkal összehasonlíthatóvá - válnak a Budapest közlekedésében bekövetkező változások. (A választások évét mindig a befejezett ciklus tevékenységéhez számítjuk.) Négy csomópont megközelítőleg húsz éves változását követjük végig: az autópálya-hálózat bővülését, az M0-s körgyürü építését, a BKV jármüállományát és annak átlagéletkorát, valamint a fővárosi kerékpárút-hálózat növekedését. 
A közlekedés jelentőségét egyértelműen mutatja 7\%-os részesedése az Európai Unió GDP-jéből (COM 2006), ezért utalunk az Európai Unió törekvéseire, előírásaira. „A közlekedéspolitika a közösségi acquis olyan része, ahol az alapvető uniós szabadságjogok nagymértékben érvényesülnek" (Zsolnay 2009, 157), melyek figyelembevétele és alkalmazása kötelességünk. „Az európai szinten kidolgozott stratégiák csak akkor válhatnak sikeressé, ha a döntő jellegü fellépések helyi szinten valósulnak meg; a konkrét fellépéseket a helyi hatóságok veszik át és hajtják végre." (Zöld Könyv 2007, 5)

Az Unió tisztában van felelősségével és lehetőségeivel: „A városi mobilitással kapcsolatos politikák csak abban az esetben lehetnek hatékonyak, ha a lehető legintegráltabb megközelítést alkalmazzák, kombinálva tehát minden egyes probléma esetében a leghelytállóbb válaszokat: müszaki innováció, a tiszta, biztonságos és intelligens közlekedési módok fejlesztése, gazdasági ösztönzés vagy jogszabályi módosítások." (Zöld Könyv 2007, 5)

\section{Autópálya-hálózat}

Miért szükséges, hogy a városi közlekedés tárgyalásakor az autópálya-hálózattal, majd az M0-s körgyürüvel is foglalkozzunk? Bár a kérdés egyszerủen megválaszolható, mögötte egy jelentős, megoldásra váró kihívás rajzolódik ki, ugyanis ,,a városi és nagyvárosi környezetben a közlekedési dugók jelensége az egyik legégetőbb probléma. [...] A dugók sok esetben a városi körgyürüket érintik, következésképpen befolyásolják a transzeurópai közlekedési hálózatok (TEN-T) müködőképességét is" (Zöld Könyv 2007, 6), így Budapest esetében is igaz, hogy uniós és nemzetgazdasági érdekek sérülnek a dugók hatására (és ekkor a környezetszennyezésről még szót sem ejtettünk). „A TEN a nemzeti hálózatok egységes, rendszer- és közösségi szemléletű kialakítását jelenti a különböző szállítási módok közötti optimális munkamegosztás és a különböző nemzeti hálózatok közötti átjárhatóságot biztosító műszaki harmonizáció figyelembevételével." (Zsolnay 2001, 12)

1990-ben az MDF egyértelműen sürgeti az autópálya-építések gyorsítását, miközben „A mai, egyoldalúan főváros-centrikus országos hálózat sugaras rendszerét fokozatosan gyürüs-hálózati rendszerré kell alakítani." (MDF 1989, 79) A Fidesz szerint is ,a hálózat anyag- és energiapazarlással járó Budapest-központúságát és Budapesten belüli centralizáltságát fokozatosan fel kell oldani” (Fidesz 1989, 26). Az MSZP és az SZDSZ programjában a közlekedésről nem esik szó. A győzelmet az MDF szerezte meg, majd hárompárti koalíció alakult a KDNP és az FKGP részvételével. Kormányprogramjukban (A Nemzeti Megújhodás... 1990) kiemelik az autópályahálózat-fejlesztési programot, melynek célja, hogy az ország területe egységesen fejlődjék, az elmaradott térségek lehetőséget kapjanak a felzárkózásra. Az autópályák jelentik az egyik legfontosabb kapcsolatot Európához. 1991-ben a 
hálózat 0,7\%-kal, 1994-ben 8,9\%-kal bővült (mindig a megelőző évi teljes hossz százalékában; KSH 2001).

Az 1994-es választások idején az autópálya-építésekre egyetlen vizsgált párt programjában sem találunk utalást. Az MSZP és az SZDSZ koalíciójával megalakuló kormány programjában (A Magyar Köztársaság... 1994) viszont célul tűzi ki az autópálya-építések befejezését. Ezzel együtt a hálózat 1995-ös 14,3\%-os, 1996-os 9\%-os, 1997-es 4,4\%-os és 1998-as 17,6\%-os bővüléséről adhatunk számot (mindig a megelőző évi teljes hossz százalékában; $K S H$ 2001). Az M3-as és M5-ös autópálya új szakaszainak elkészültét az Európai Bizottság is üdvözölte a Magyarország csatlakozásra való felkészülését vizsgáló első, 1998-as országjelentésében (CEC 1998).

1998-ban az MSZP szerint az infrastruktúra fejlesztésénél Magyarország regionális tranzithelyzetére kell alapozni: az autópályákat az országhatárig kell megépíteni és gyürüirányba is fejleszteni. Ezt azonban nem a választási program, hanem egy szakmai füzet (Puch-Soós 1998) tartalmazza. A másik három párt választási programjában nem tesz utalást autópálya-építésekre. A hatalomra kerülő Fidesz-MDFFKGP koalíció kormányprogramjában azt írják, hogy mindent meg kívánnak tenni „a megkezdett autópályák építésének gyorsításáért" (Az új évezred... 1998, 26). Az Európai Bizottság országjelentéseiben (CEC 2000; 2001) szóvá teszi, hogy még nem épültek új autópályák, ugyanakkor megemlíti, hogy ígéretet kaptak ennek megváltoztatására, és hogy Magyarország figyelembe veszi a TEN-T hálózat céljait és prioritásait. Végül 2002-ben a hálózat 19\%-kal bővült (a megelőző évi teljes hossz százalékában; KSH 2008).

2002-ben hasonló a helyzet a nyolc évvel korábbihoz: sem a választásokon koalícióban induló Fidesz és MDF, sem az MSZP, sem az SZDSZ nem említ autópályaépítést választási programjában. A választások után megalakuló MSZP-SZDSZ kormány programjában olvasható, hogy „Stratégiai cél az M0, M3, M5, M7 autópályák és a kapcsolódó gyorsforgalmi utak építésének befejezése, illetve folytatása” (Cselekedni, most és... 2002). 2004-ben miniszterelnök-váltás történt, mely egyúttal új kormányprogramot is jelentett, azonban abban ismét nem esik szó az autópályákról. Ettől függetlenül a ciklusban nőtt a hálózat: 2003-ban 1,7\%-kal, 2004-ben 5\%-kal, 2005-ben 11,8\%-kal, 2006-ban pedig 23,4\%-kal (a megelőző évi teljes hossz százalékában; $K S H$ 2008).

2006-ban sem lehetett olvasni autópálya-építésekről sem a választási programokban, sem a kormányprogramban. A rendelkezésünkre álló adatok alapján 2007-ben 9,3\%-kal, 2008-ban pedig 6,2\%-kal bővült a hálózat, ami 911 km-es teljes hosszt jelent (a megelöző évi teljes hossz százalékában; $K S H$ 2008).

Az újonnan épült km-eket és a teljes hossz 20 éves adatait - ciklusonkénti bontásban - az 1. ábra mutatja. 


\section{1. ÁBRA}

Autópálya-hálózat növekedése, 1990-2008

(The Expansion of the Hungarian Motorway-network, 1990-2008)

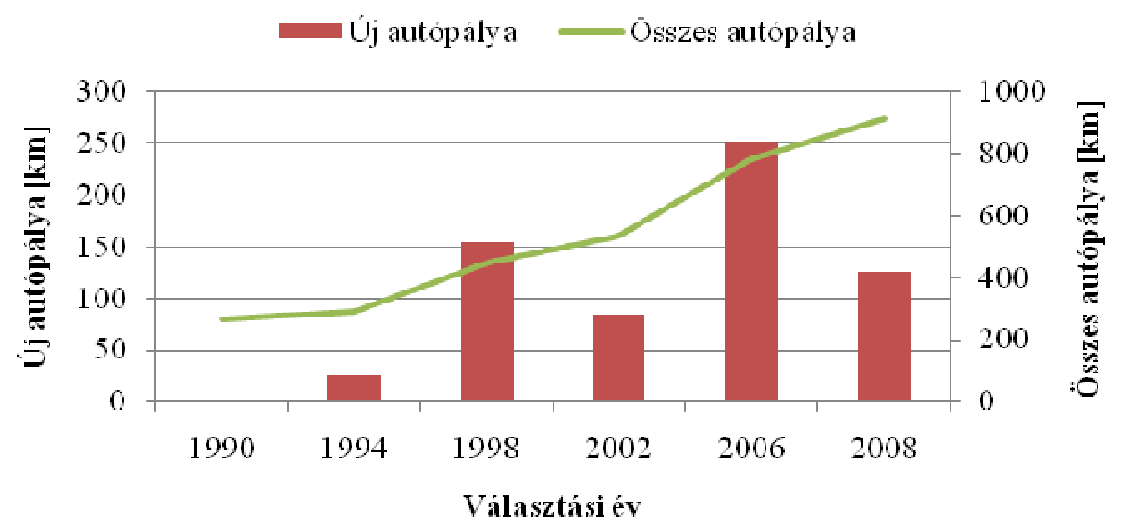

Forrás: KSH-adatok alapján saját szerkesztés.

\section{MO-s körgyürü}

A körgyürü építését 1987-ben kezdték el. Rákövetkező évben átadtak ugyan egy 6 km-es darabot, de egy hosszabb, 15 km-es szakasz 1990-ben készült el. (http://www.autopalya.hu/engine.aspx?page=M0_tortenet)

1990-ben csak a Fidesz említi az M0-st: fontos, hogy „ne halogassák tovább a várost kikerülő főútvonalak (körgyürü) megépítését" (Fidesz 1989, 26). Az MSZP és az SZDSZ nem tesznek említést a körgyürüről, ahogy a választási-, majd első kormányprogramjában az MDF sem. 1993-ban az új miniszterelnök kormányprogramjában (Kormányprogram a ... 1993) az M0-s befejezését ígérik. (Jegyezzük meg, még ma sem teljes.) 1994-ben egy $15 \mathrm{~km}$-es szakasz átadására került sor (http://www.autopalya.hu/engine.aspx?page=M0_tortenet).

1994-ben és 1998-ban sem a pártok választási-, sem a kormány programjában nem szerepel a körgyürü. A korábbi ciklus alatt nem is épült meg újabb szakasza, de azt követően, 1999-ben 6 km készült el.

A választásokon 2002-ben koalícióban induló Fidesz és MDF megígéri az M0-s északi, déli és keleti szektorának, valamint északi hídjának megépítését (Fidesz $M P P-M D F$ 2002). Az MSZP is szól a körgyürüről, de nem választási programjában, hanem a Közlekedési szakmai füzetben (A jóléti rendszerváltás... 2001): Budapest átmenő forgalmát és így zsúfoltságát az M0-s körgyürű megépítésével, illetve autópályává bővítésével kell csökkenteni. Az MSZP-SZDSZ koalíció első kormányprogramja (Cselekedni, most és... 2002) stratégiai célnak nevezi az M0 befejezését (a másodikban nem említik), de csak egy 12 km-es szakasz készül el 2005-ben. 
2006-ban a Fidesz (Fidesz 2006) és az MSZP választási programjában (MSZP 2006) egyaránt szerepel az M0 befejezése (a két kisebb pártében nem), utóbbiból át is kerül az MSZP-SZDSZ kormány programjába (Új Magyarország... 2006). El ugyan ebben a ciklusban sem készült, de az eddigi leghosszabb egybefüggő szakasz átadásával az M0-sból mintegy 80 km-es darab van készen (http://www.autopalya.hu/ engine.aspx?page=M0_tortenet) (2. ábra).

\section{2. ÁBRA}

Az MO-s körgyürü bövülése

(The Expansion of the MO Ring-road)

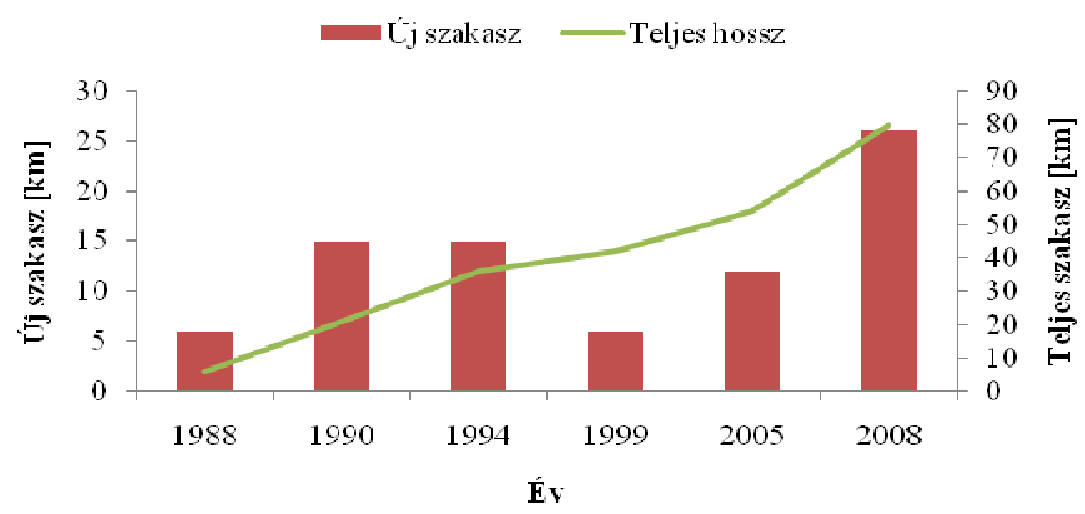

Forrás: Saját szerkesztés.

\section{$B K V$ jármüpark}

1990-es választási programjában az MDF (MDF 1989) és a Fidesz (Fidesz 1989) a közforgalmú közösségi közlekedés egyénivel szembeni támogatása mellett és környezetkímélö jármüpark kialakítása mellett állt ki. A hárompárti kormány programja (A Nemzeti Megújhodás.. 1990) azt is megállapítja, hogy a jármüparkban eleve sok a csereérett. A ciklusban 423 db új autóbusz és 3 db troli érkezett, mindegyik az Ikarustól, továbbá 10 új metrókocsival is bővült a jármüpark ( $B K V$ éves jelentések). A trolik átlagéletkora javult a legnagyobb mértékben.

1994-ben semelyik párt választási programjában nem szerepel a közforgalmú közösségi közlekedés, ahogy az MSZP-SZDSZ kormány programjában sem. Ennek ellenére a BKV jármüparkja 163 db autóbusszal és 13 db trolival bővült ( $B K V$ éves jelentések). 1995-ben valamelyest csökkent az előbbiek átlagéletkora.

1998-ban egyedül az MDF (MDF 1998) tett ígéretet a közforgalmú közösségi közlekedés felé: választási programjában környezetbarát autóbuszok beszerzését támogatja. A többi párt programja nem tartalmazott hasonlókat. A Fidesz-MDF kormány programjában (Az új évezred... 1998) a közforgalmú közösségi közlekedés vonzóbbá tételét tűzik ki célul különféle fejlesztések segítségével, ami magában 
foglalja a korszerü és takarékos autóbusz-állomány kialakítását is. Budapestre $115 \mathrm{db}$ új autóbusz (egy kivételével mind Ikarus, bár az Irisbus fejlesztette Agorára is ez a márkanév került), $15 \mathrm{db}$ új troli (szintén Ikarusok) és $10 \mathrm{db}$ új metrókocsi érkezett. 2001-ben került beszerzésre Hannoverből 76 db használt villamos is (BKV éves jelentések). Egyik alágazat esetében sem beszélhetünk az állomány megfiatalodásáról.

2002-ben a jármüpark fejlesztéséről és korszerüsítéséről egyik párt választási programjában sem olvashatunk, csak a választásokat követően megalakuló MSZPSZDSZ kormány (Cselekedni, most... 2002) pontjai között szerepel (a 2004-es új kormányprogramban már nem). A BKV jármüparkja ismét jelentős fejlesztésen esett át, ráadásul ekkor már nem orosz jármủvek jelentik a frissítést. Ekkor érkezett a $150 \mathrm{db}$ Volvo busz és $15 \mathrm{db}$ Ganz trolibusz, illetve a Siemens Combino villamosok első 26 darabja (BKV éves jelentések). Az alágazatok jármüveinek átlagéletkorán meglátszik az új eszközök érkezése.

2006-ban a pártok választási programpontjai közül több is érinti a BKV hálózatát, de nem kifejezetten járművekről, hanem magának a hálózatnak a bővítéséről szólnak ezek, amivel viszont mi most nem foglalkozunk. Az SZDSZ (SZDSZ 2005) az egyetlen párt ebben az évben, amely jobb minőségü, így vonzóbb közforgalmú közösségi közlekedés kialakítását tüzi ki célul. Az MSZP-SZDSZ kormány programjában (Új Magyarország... 2006) is szerepel a közösségi közlekedés fejlesztése és fenntartása. BKV-beszerzések 2007-ben és 2009-ben történtek: előbb megérkezett a hátralévő $14 \mathrm{db}$ Combino, valamint $10 \mathrm{db}$ Ganz-Skoda trolibusz (BKV éves jelentések), majd 2009-ben került sor a 32 db használt belga Van Hool busz megvásárlására is. Ezen felül említésre méltó, hogy a 2-es metró vonalára rendelt Alstom Metropolis kocsikból is üzembe helyeztek már néhányat.

\section{3. ÁBRA}

A BKV jármüállománya, 1990-2008

(Number of the BKV's Vehicles, 1990-2008)

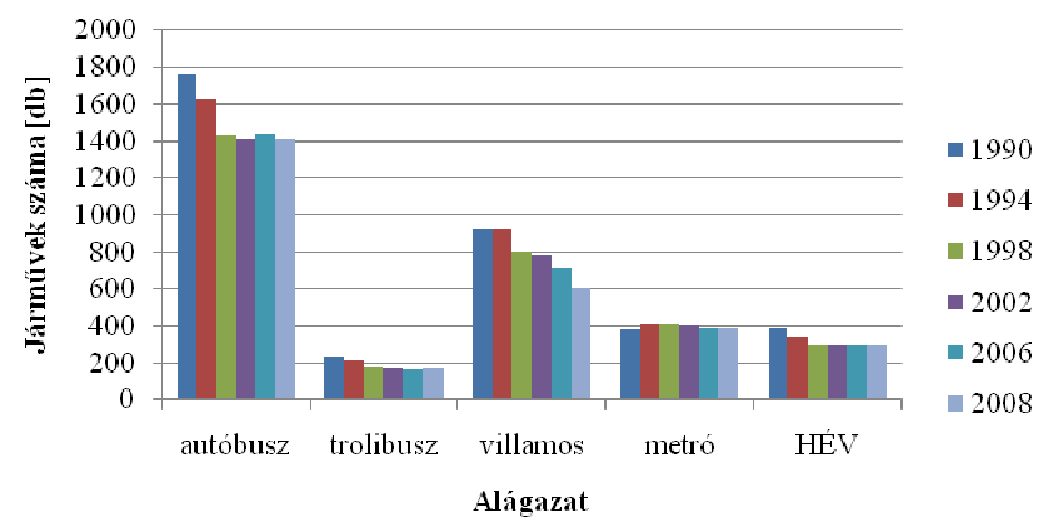

Forrás: A BKV éves jelentései alapján saját szerkesztés. 
Az évek során természetesen - alapvetően a koruk miatt - az idősebb járművek selejtezésére is sor került. Összességében elmondhatjuk, hogy az 1990-es induló állomány több mint 30\%-a újult meg. Mindezek fényében a 3. és 4. ábra mutatja ciklusonkénti bontásban - a BKV jármüparkját és annak átlagéletkorát alágazatonként.

\section{4. ÁBRA}

A BKV jármüveinek átlagéletkora, 1990-2006

(Mean Age of the BKV's Vehicles, 1990-2006)

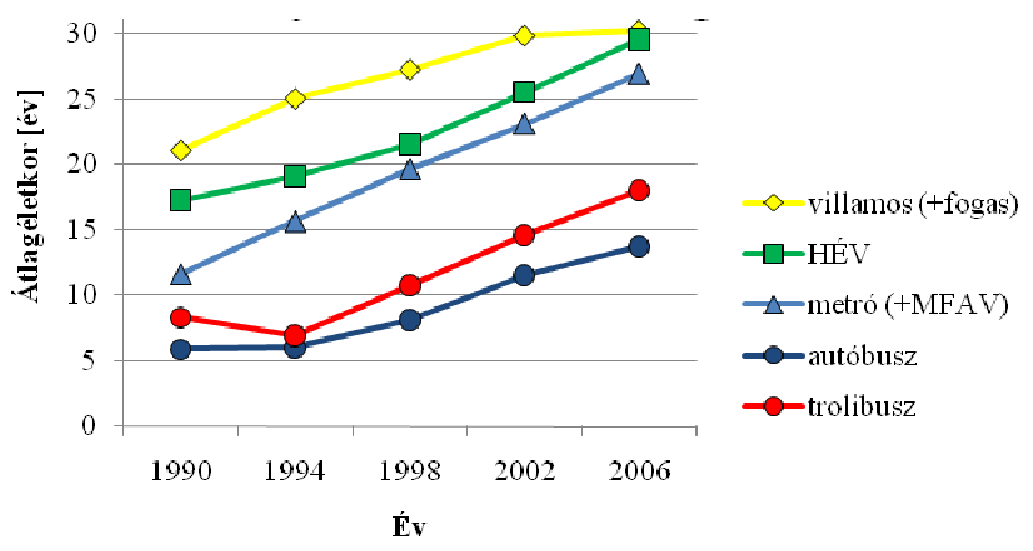

Forrás: Saját szerkesztés.

\section{Kerékpárút-hálózat}

Az Unióban és hazánkban is egyre népszerübb a városon belüli kerékpárhasználat. „A jó minőségü infrastruktúra, beleértve a gyalogosok és a kerékpárosok számára kialakított jó minőségü utakat, nagy szerepet játszhat" a közlekedés minden résztvevője számára fontos biztonságérzet (Szőcs 2005) kialakulásában és megerősítésében.

1990-ben a Fidesz (Fidesz 1989) az egyetlen párt, amely foglalkozik a kerékpárosok közlekedésével. Választási programjuk szerint ez a közlekedési mód - a belső városrészekben akár a gépjármúforgalom rovására is - támogatandó, ami véleményünk szerint - magyar viszonylatban legalábbis - egy korát megelőző gondolat. A másik három párt a választások előtt nem tett erre vonatkozó pontot a programjába. A választásokat követően pedig a második kormányfő programjáig (Kormányprogram... 1993) kellett várni, hiszen ebben a koalíció kerékpárút-építésekre tett ígéretet. A hálózat hosszára vonatkozó adatokat ebből az időből nem találtunk, de azt tudjuk, hogy a ciklusban 282 millió Ft-ot költöttek a kerékpárutak építésére (A föváros elkötelezett... 2009). 
1994-ben sem a választási programokban, sem a kormányprogramban nem esik szó a kerékpárosokról. Ennek ellenére a ciklusban 429 millió Ft-ot költöttek kerékpárút-építésekre. 1998-ban a budapesti hálózat hossza meghaladta a 100 km-t (A föváros elkötelezett... 2009).

1998-ban az MDF (MDF 1998) a költségkímélö közlekedési formák, a kerékpárés gyalogos közlekedés támogatásáról biztosította a választópolgárokat, a Fidesz (Fidesz 1998) pedig konkrétan kerékpárutak építésével kampányolt. A korábbi kormánykoalíció pártjai még ekkor sem gondoltak a kétkerekű jármű használóira. A hatalmat megszerző Fidesz-MDF kormány programjába sajnos már nem kerültek bele az említett pontok. Ezzel együtt 684 millió Ft-ot költöttek a fővárosban a hálózat bővítésére, így 2002-re a teljes hossz a 140 km-t súrolta (A föváros elkötelezett... 2009).

2002-ben egyedül az MSZP-nél kerül elő a téma, azonban náluk sem a választási program tartalmazza, hanem a már említett Közlekedési szakmai füzet (A jóléti rendszerváltás... 2001). Ebben hívják fel a figyelmet arra, hogy a kerékpárutak hálózattá fejlesztésére van szükség. Ez a kitétel azonban már sem a 2002-es, sem a 2004-es (MSZP-SZDSZ) kormányprogramba nem kerül át. Talán van összefüggés e tény és aközött, hogy ebben a ciklusban a korábbiaknál kevesebb, 215 millió Ft-ot költöttek kerékpárutak kialakítására. Ugyanakkor 2006-ra 170 km-esre bővült a hálózat (A föváros elkötelezett... 2009).

2006-ban is csak egyetlen párt, ezúttal az SZDSZ (SZDSZ 2005) áll ki a kerékpárút-hálózat fejlesztése mellett, azonban hiába marad a párt részese a koalíciónak a választások után, a kormányprogramba megint nem kerül már be ez a pont, ugyanakkor két év alatt 17 km-nyi új szakasz épült (A fơváros elkötelezett... 2009). A hálózat bővülését az 5. ábra mutatja.

\section{5. ÁBRA}

A kerékpárút-hálózat növekedése, 1998-2008

(The Expansion of the Bicycle Road Network, 1998-2008)

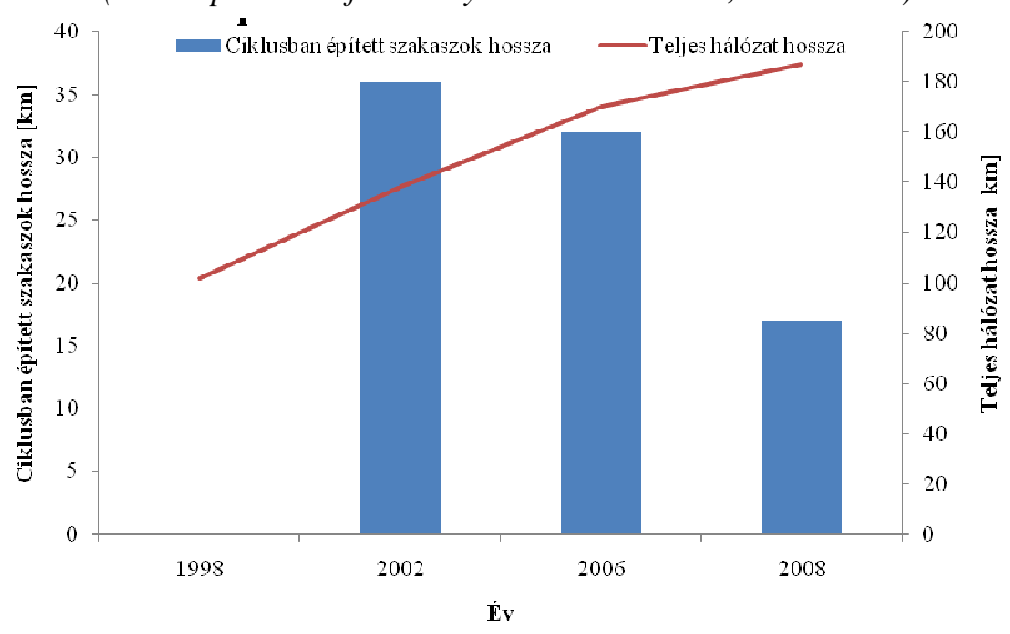

Megjegy zés: az 1994-1998-as ciklusuju szakaszolira vonatkozo adatai hianyosak

Forrás: A főváros elkötelezett... (2009) alapján saját szerkesztés. 


\section{Összefoglalás}

A fentieket összesítve elmondhatjuk, hogy a magyarországi autópálya-hálózat mintegy húsz év alatt kb. a négyszeresére nőtt, miközben az M0-s körgyürü is - ha körbe ugyan még mindig nem ér, de - többszörösére növekedett, nagyban hozzájárulva a főváros tehermentesítéséhez.

A BKV hálózata is valamelyest kiterjedtebb, mint 1990-ben, de az autóbusz alágazatnak ebben döntő szerepe van. Bár el kell ismerni, hogy még mindig sok régi, a környezetet jobban megterhelö jármü közlekedik, rendszeresen találkozni frissen felújított példányokkal. Az 1990-es állomány harmada lecserélődött, többségében új jármủvekkel, a használhatatlan régiek pedig selejtezésre kerültek.

Ami pedig a kerékpárosok közlekedését érinti, a kerékpárút-hálózat is aránylag rendszeresen növekszik.

Úgy gondoljuk, hogy az adatok magukért beszélnek. Nem állt meg, mert nem is állhatott meg Budapest közlekedésének fejlesztése egy pillanatra sem. Sajnálatos, hogy ezek az eredmények eltörpülnek a (negatív) szenzációk mellett. Bár van okunk örülni ezeknek a változásoknak, a jövő kihívásaira válaszokat adni sem lesz egyszerü.

\section{Irodalom}

A BKV éves jelentései. http://www.bkv.hu/evesjelentes/index.html

CEC (1998) Regular Report from the Commission on Hungary's progress towards accession. Commission of the European Communities, Brussels.

CEC (2000) Regular Report from the Commission on Hungary's progress towards Accession. 8 November 2000. Commission of the European Communities, Brussels.

CEC (2001) Regular Report on Hungary's progress towards Accession. SEC(2001)1748 Commission of the European Communities, Brussels.

COM (2006) Tartsuk mozgásban Európát! - Fenntartható mobilitás kontinensünk számára. Az. Európai Bizottság 2001. évi közlekedéspolitikai fehér könyvének félidei felülvizsgálata. 22.6.2006. COM(2006)314 Az Európai Közösségek Bizottsága, Brüsszel.

Cselekedni, most és mindenkiért! A nemzeti közép, a demokratikus koalíció Kormányának programja. Magyarország 2002-2006. (2002)

Fidesz (1989) A FIDESZ II. kongresszusa által elfogadott program. 1989. október 13-15.

Fidesz (1998) Szabadság és jólét. A polgári jövö programja, 1998.

Fidesz (2006) Hajrá, Magyarország! A Cselekvö Nemzet Programja.

Fidesz MPP-MDF (2002) A jövő elkezdődött: Fidesz, Magyar Polgári Párt-MDF választási program 2002. Február 16. Budapest.

A föváros elkötelezett a kerékpáros közlekedés fejlesztése mellett. (2009) Háttéranyag. Budapest Főváros Önkormányzata, Föpolgármesteri Hivatal, Budapest. http://www.budapest.hu/resource.aspx? ResourceID=kerekpar_fovaros

A jóléti rendszerváltás programjának szakmai vitaanyagai. (2001) Közlekedési szakmai füzet. 21. vitaanyag. November.

Kormányprogram a folyamatosság, a stabilitás és a fejlödés jegyében. (1993) December 20. Budapest.

KSH (2001) Magyar statisztikai évkönyv, 2000. Központi Statisztikai Hivatal, Budapest.

KSH (2008) Magyar statisztikai évkönyv, 2007. Központi Statisztikai Hivatal, Budapest.

A Magyar Köztársaság Kormányának Programja 1994-1998 (Tervezet). (1994) Július 8. Budapest.

MDF (1989) Magyar Demokrata Fórum Programja. 1989. október.

MDF (1998) Biztonságot a mindennapoknak! A Magyar Demokrata Fórum Programja. 1998. március 1. XII. Országos Gyülés, Gödöllő.

MSZP (2006) Biztonság, igazságosság, bátorság. A Magyar Szocialista Párt választási programja. 
A Nemzeti Megújhodás Programja. A Köztársaság első három éve. (1990) Szeptember. Budapest.

Puch L.-Soós Gy. (szerk.) (1998) A felzárkózás gazdaságpolitikája. Gazdaságpolitikai szakmai füzet.

SZDSZ (2005) Szabadság, verseny, szolidaritás 2006-2010. A Szabad Demokraták Szövetsége választási programja. Az Országos Tanács által elfogadott javaslat a küldöttgyülésnek. 2005. december 3.

Szőcs L. (2005) Akinek szitokszó a fekvőrendőr. - Népszabadság. március 23. http://www.nol.hu/archivum/archiv-356221

Az új évezred küszöbén. Kormányprogram a polgári Magyarországért. (1998) Budapest.

Új Magyarország. Szabadság és szolidaritás. A Magyar Köztársaság Kormányának programja a sikeres, modern és igazságos Magyarországért 2006-2010. (2006) Magyar Hivatalos Közlönykiadó, Budapest. Zöld Könyv. A városi mobilitás új kultúrája felé. (2007) COM(2007)551 Az Európai Közösségek Bizottsága, Brüsszel.

Zsolnay T. (2001) Közlekedés az Európai Unióban. A Magyar Köztársaság Külügyminisztériuma, Budapest.

Zsolnay T. (2009) Magyarország és az uniós közlekedéspolitika. - Európai Tükör. Magyarország öt éve az Európai Unióban 2004-2009. Különszám. Március. 157-170. o. 